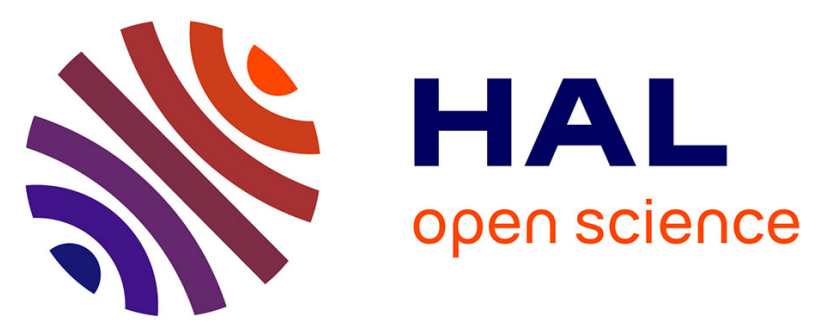

\title{
A Fully Biobased Epoxy Resin from Vegetable Oils: From the Synthesis of the Precursors by Thiol-ene Reaction to the Study of the Final Material
} Mylene Stemmelen, Freddy Pessel, Vincent Lapinte, Sylvain Caillol, Jean-Pierre Habas, Jean-Jacques Robin

\section{To cite this version:}

Mylene Stemmelen, Freddy Pessel, Vincent Lapinte, Sylvain Caillol, Jean-Pierre Habas, et al.. A Fully Biobased Epoxy Resin from Vegetable Oils: From the Synthesis of the Precursors by Thiol-ene Reaction to the Study of the Final Material. Journal of Polymer Science Part A: Polymer Chemistry, 2011, 49 (11), pp.2434. 10.1002/pola.24674 . hal-00587993

\section{HAL Id: hal-00587993 https://hal.science/hal-00587993}

Submitted on 22 Apr 2011

HAL is a multi-disciplinary open access archive for the deposit and dissemination of scientific research documents, whether they are published or not. The documents may come from teaching and research institutions in France or abroad, or from public or private research centers.
L'archive ouverte pluridisciplinaire HAL, est destinée au dépôt et à la diffusion de documents scientifiques de niveau recherche, publiés ou non, émanant des établissements d'enseignement et de recherche français ou étrangers, des laboratoires publics ou privés. 


\title{
A Fully Biobased Epoxy Resin from Vegetable Oils: From the Synthesis of the Precursors by Thiol-ene Reaction to the Study of the Final Material
}

\author{
M. STEMMELEN, F. PESSEL, V. LAPINTE, S. CAILLOL, J.-P. HABAS, J.-J. ROBIN \\ Institut Charles Gerhardt Montpellier UMR5253 CNRS-UM2-ENSCM-UM1, Equipe Ingénierie et Architectures \\ Macromoléculaires, Université Montpellier II, Bat 17 - cc1702, Place Eugène Bataillon 34095 Montpellier Cedex 5, France
}

Received 4 February 2011; accepted 14 March 2011

DOI: $10.1002 /$ pola.24674

Published online 8 April 2011 in Wiley Online Library (wileyonlinelibrary.com).

\begin{abstract}
A novel vegetable oil-based polyamine issued from grapeseed oil (GSO) was prepared using cysteamine chloride (CAHC) by thiol-ene coupling (TEC). The structure of the polyamine oil (AGSO) was carefully examined using a large range of chemical analyses (FTIR, ${ }^{1} \mathrm{H}$ NMR and ${ }^{13} \mathrm{C}$ NMR, LC-MS...). The effects of the amination of GSO on the vegetable oil properties were also studied using viscosimetry. Then, AGSO was employed as a novel curing agent for bio-based epoxy resin. The thermal crosslinking reaction between AGSO and epoxi-
\end{abstract}

dized linseed oil (ELO) was studied by DSC and rheology. This study also dealt with the definition of the thermomechanical properties of the final material obtained by the mixing and curing of AGSO with ELO in stoichiometric proportions. (C) 2011 Wiley Periodicals, Inc. J Polym Sci Part A: Polym Chem 49: 2434-2444, 2011

KEYWORDS: biomaterials; crosslinking; glass transition; photochemistry; renewable resources
INTRODUCTION Polymers derived from renewable resources are gaining a great interest due in part to the rarefaction of fossil raw materials. ${ }^{1}$ The chemistry based on vegetable feedstock felt into disuse during the last decades with the emergence of synthetic polymers. Beside polysaccharides, polypeptides and so on, lipids are a class of versatile materials with complex compositions that can be transformed by chemical processes and open the way to new materials ${ }^{2,3}$ such as polyurethanes, ${ }^{4,5}$ polyamides, ${ }^{6}$ surfactants. ${ }^{7}$ Epoxide based resins belong to a class of materials with very interesting properties in terms of mechanical and thermal behaviors. But, the substitution of bis-phenol A based epoxy resins by materials coming from vegetable oil remains as a challenge for scientists.

Triglycerides including a large variety of unsaturations can be easily epoxidized using enzymatic process ${ }^{8}$ or usual organic methodologies ${ }^{9,10}$ where the couple $\mathrm{H}_{2} \mathrm{O}_{2} / \mathrm{HCOOH}$ acts efficiency onto various triglycerides. Linseed oil is still the most famous epoxidized oil which is used as plasticizer or additive in the processing of PVC. The oxirane ring is useful for further conversion in other chemical functions such as carbonate, $^{11,12}$ alcohol $^{13,14}$ but also for the synthesis of thermosetting resins by crosslinking with anhydride or amine functions or by homopolymerization of oxirane rings initiated by catalysts. ${ }^{15}$ Few authors tried to apply this strategy to renewable materials mainly using commercial epoxidized linseed oil (ELO) ${ }^{16}$ to lead to various materials exhibiting toughness due to long alkyl chains of the triglycerides. But the approach consisting in hardening epoxy resins coming from biomass with hardeners derived from petroleum is not satisfactory in term of concepts of green chemistry. ${ }^{17}$ So, this article proposes to develop crosslinking materials from renewable resources and an original new epoxy system where both epoxide resin and its amine based hardener are synthesized by simple modification of polyunsaturated oils.

Amines are most often used for crosslinking of polyepoxides since their nucleophilicity make them reactive at room temperature. Some attempts to convert lipids or compounds derived from lipids into amines or polyamines have been described. Biermann et al. ${ }^{18}$ reviewed different methods to functionalize unsaturated fatty acids. The use of manganese III acetate mediated addition of sodium azide followed by the catalytic reduction of the azide group to give the corresponding amine was explored but not extended to triglycerides. Aziridines have been synthesized from unsaturated fatty acids in a two steps process but this function does not behave as an amine group in crosslinking of polymer. ${ }^{9,19}$ Recently, Zhao et al. $^{20}$ prepared secondary amines in a five steps process starting from epoxidized triglycerides. The oxirane groups were transformed into diols which were brominated using $\mathrm{P}(\mathrm{Ph})_{3}$. At last, the displacement of the bromine groups with sodium azide and the subsequent catalytic reduction gave the expected polyamine. Some attempts in enzymatic biotransformation showed an interest in the production of polyamine through the obtention of an azadicarboxylate diethyl ester derivative of soybean oil. The 
conversion of this derivative in alkaline conditions led to a substituted hydrazine. ${ }^{21,22}$ The same authors discovered another method to produce an oleate-aniline adduct using catalytic amount of ionic liquids. ${ }^{23}$ The use of nitrile compounds as precursors of amines after catalytic reduction has also been tested with fatty acids. ${ }^{24}$ The addition of an excess of diamine onto an epoxidized vegetable oil under controlled experimental conditions can lead to an amine functionalized fatty acids. ${ }^{25,26}$ All these works showed that only few polyamines have been synthesized in the past from renewable resources. Moreover, the applied methodologies imply multistep processes with low yields and formation of many by-products. Thus, we present here a new concept for the synthesis of polyamine based on unsaturated triglycerides thanks to the thiol-ene reaction. This last has been extensively studied in the past and re-emerge now with the development of the click-chemistry concept. ${ }^{26}$ This simple reaction is very attractive due to its simple processing despite unpleasant odor of mercaptans. It can be performed under thermal initiation or UV light irradiation ${ }^{27}$ with higher reaction rates. Contrary to usual radical reaction involving peroxides, the presence of oxygen is not damaging making this chemistry useful in industrial processes. ${ }^{28}$ Boutevin et al. synthesized hetero-atoms containing thiols which were subsequently added onto polydienes ${ }^{29-31}$ and PDMS. ${ }^{32}$ Some attempts to functionalize fatty acids and triglycerides have been achieved ${ }^{33-37}$ and crosslinking of functionalized castor oil using polyfunctional thiols has also been reported. ${ }^{38}$ Branched polymers were also synthesized according to this process. $^{39}$ At last, vegetable oils have been modified by mercaptans to improve their lubricating properties. ${ }^{40,41}$

In this article, we describe the functionalization of grapeseed oil (GSO) with amine groups involving the thiol-ene reaction. The addition of a mercaptan bearing also an amine function has never been described since both functions are not chemically stable when they belong to the same molecule. Furthermore, the second originality of this article results in the synthesis of a polyepoxide system where both resin and hardener are based on modified natural oils. The use of an aminated oil as crosslinking agent for ELO leading to a totally bio-sourced thermosetting resin is detailed and the crosslinking reaction step is followed by rheology. The same technique is retained to investigate the thermomechanical properties of the crosslinked material. Indeed, if different oilbased epoxy resins were investigated in the literature, the viscoelastic properties of the derived material are more rarely detailed. Moreover, the published works concern cured polymer obtained by the reaction of an epoxidized vegetable oil with anhydride ${ }^{42}$ or polyamine hardeners ${ }^{43}$ issued from petrochemistry.

\section{EXPERIMENTAL}

\section{Materials}

GSO was commercial product. Cysteamine hydrochloride (CAHC), 1,4-dioxane (CARLO ERBA), absolute ethanol (CARLO ERBA), acetonitrile (ACN), diethyl ether, $n$-hexane, trifluoroacetic acid (TFA), 2,2-dimethoxy-2-phenylacetophe- none (DMPA) (99\% Aldrich) were used as received. Trimethylbenzoyldiphenylphosphine (TPO) and ELO were generous gifts, respectively from BASF and ARD. Deuterated chloroform $\left(\mathrm{CDCl}_{3}\right)$ was purchased from SDS and was used without further purification.

\section{Analytical Techniques}

${ }^{1} \mathrm{H}$ and ${ }^{13} \mathrm{C}$ NMR spectra were recorded using a Bruker AVANCE spectrometer $\left({ }^{1} \mathrm{H}\right.$ at $300 \mathrm{MHz},{ }^{13} \mathrm{C}$ at $\left.75.47 \mathrm{MHz}\right)$ with $\mathrm{CDCl}_{3}$ as solvent. The DEPT technique allows one to quickly identify carbon atoms according to the number of directly attached protons. The DEPT-135 experiment shows $-\mathrm{CH}_{3}$ and $-\mathrm{CH}-$ carbons with positive phase and $-\mathrm{CH}_{2}-$ carbons with negative phase. Quaternary carbons do not appear in any DEPT spectrum. Chemical shifts $\left({ }^{1} \mathrm{H}\right.$ NMR) were referenced to the peak of residual $\mathrm{CHCl}_{3}$ at $7.26 \mathrm{ppm}$. Chemical shifts $\left({ }^{13} \mathrm{C}\right.$ NMR) were referenced to $\mathrm{CDCl}_{3}$ at 77 ppm.

Differential scanning calorimetry (DSC) analyses were carried out using a Mettler Toledo Star1 apparatus. First experiment was conducted on the reactive mixture (AGSO + ELO) in stoichiometric proportions to investigate the temperature domain associated to the crosslinking reaction. The same technique was also employed to evaluate the glass transition temperature of the cured polyepoxide system. In both cases, the sample was set in an aluminum pan that was consecutively placed in the measurement heating cell and an empty pan was used as reference. These calorimetric experiments were realized under inert atmosphere with a heating rate fixed at $10{ }^{\circ} \mathrm{C} / \mathrm{min}$.

Rheological experiments were performed using a stress-controlled dynamic rheometer (AR2000Ex from TA). This apparatus was equipped with an environmental testing chamber to allow the registering of the complex shear modulus $G^{*}=$ $G^{\prime}+j G^{\prime \prime}$ under precise control of the temperature. The component $G^{\prime}$, called "storage modulus," represents the mechanical rigidity of the sample (i.e., its elastic contribution) whereas the loss modulus $G^{\prime \prime}$ relates to the dissipated mechanical energy. The behavior of the reactive mixture was investigated using a cup-plate geometry that was suitable to the characterization of an evolutive system from the liquid to the solid state. The inner diameter of the cup was $25 \mathrm{~mm}$ while the upper plate was much smaller $(10 \mathrm{~mm})$ to prevent undesirable side effects. The thermomechanical properties of the cured polymer were characterized with the same rheometer but equipped with rectangular torsion geometry that was judged more convenient for studying rigid samples. In this latter case, typical dimensions of the specimens were $40 \mathrm{~mm} \times 10 \mathrm{~mm} \times 2 \mathrm{~mm}$. The thermomechanical tests were carried out at a heating rate of $3{ }^{\circ} \mathrm{C} / \mathrm{min}$ from $-150{ }^{\circ} \mathrm{C}$ to $150{ }^{\circ} \mathrm{C}$ and at a constant oscillating angular frequency $(\omega=1 \mathrm{rad} / \mathrm{s})$.

Fourier Transform Infrared (FTIR) spectra were recorded with a Perkin-Elmer Spectrum 100 spectrometer equipped with an attenuated total reflectance (ATR) crystal made of ZnSe. 
Lipid identification by Thin Layer Chromatography (TLC): lipids were separated on silica gel plates using $n$-hexane/ diethyl ether $(70: 30 \mathrm{v} / \mathrm{v})$. Compounds were visualized by spraying the TLC plates with dilute $15 \%$ aqueous sulfuric acid, followed by charring at $150{ }^{\circ} \mathrm{C}$ for a few minutes. The degradation of crude GSO was observed by this technique. to estimate the influence of the temperature and the UV radiation on GSO, a sample was heated for 4 days at $80{ }^{\circ} \mathrm{C}$ and another one was submitted to UV radiation for $8 \mathrm{hrs}$. Each one was deposited on a TLC plate.

Transformation into FAMES and GC Analysis of fatty acid (FA) composition: In 25-mL round-bottom flasks, $10 \mathrm{mg}$ of samples were added to $3 \mathrm{~mL}$ sodium methylate solution with phenolphthalein. The reaction medium was refluxed for $10 \mathrm{~min} ; 3 \mathrm{~mL}$ of chlorhydric methanol was added to phenolphthalein discoloration. The mixture was refluxed again for $10 \mathrm{~min}$ and then cooled to ambient temperature; $8 \mathrm{~mL}$ hexane and $10 \mathrm{~mL}$ water were added, and the organic phase was recovered, dried over anhydrous sodium sulfate and filtered for subsequent GC analysis: Agilent 6890 series using a Supelcowax 10 capillary column (SGE, Courtaboeuf, France) with the following characteristics: length, $30 \mathrm{~m}$; internal diameter, $0.32 \mathrm{~mm}$; film thickness, $0.25 \mu \mathrm{m}$. Fatty acid methyl esters were directly injected into the GC. Carrier gas: helium flow rate $20 \mathrm{~mL} / \mathrm{min}$, splitting ratio: 100, injector temperature: $250{ }^{\circ} \mathrm{C}$, FID detector temperature: $270{ }^{\circ} \mathrm{C}$. The temperature settings were as follows: $185-240{ }^{\circ} \mathrm{C}$ at $4{ }^{\circ} \mathrm{C} / \mathrm{min}, 225^{\circ} \mathrm{C}$ for $10 \mathrm{~min}$.

The HPLC/ESI system consisted of a capillary HPLC system (Alliance 2790, Waters) and an ESI source of time-of flight (TOF) mass spectrometer (Q-TOF, Waters). The system was controlled by ChemStation software (Waters). The separations were performed on a BDS Hypersil C18 (Thermo) analytical column ( $3 \mu \mathrm{m}$ particle size, $2.1 \mathrm{~mm}, 50 \mathrm{~mm}$ ). Typical elution conditions were to begin by maintaining $90 \%$ mobile phase A $\left(\mathrm{H}_{2} \mathrm{O}+1 / 1000 \mathrm{TFA}\right)$ and $10 \%$ mobile phase $\mathrm{B}(\mathrm{ACN}+1 /$ 1000 TFA) by an increase in solvent B from 10 to $100 \%$ in 30 min with a 5 -min hold at $100 \% \mathrm{~B}$. The flow rate was set at $0.2 \mathrm{~mL} / \mathrm{min}$, and the injection volume was $40.0 \mu \mathrm{L}$. The column was preconditioned by running a blank with the above elution profile and then pumping mobile phase A for an additional $15 \mathrm{~min}$. LC/ESI-MS chromatograms were acquired in the positive ion mode with the capillary voltage set at $3000 \mathrm{~V}$ and cone voltage at $30 \mathrm{~V}$ while the dry temperature was set at $350{ }^{\circ} \mathrm{C}$ and dry gas flow was maintained at $13 \mathrm{~L} / \mathrm{min}$. The mass acquisition range was from $\mathrm{m} / \mathrm{z} 50$ to 1500 .

\section{Characterization of Grape Seed Oil: GSO}

GSO contains predominantly the diunsaturated linoleic acid (65.9\% C18:2) in its structure. In addition, grape seed oil contains unsaturated palmitoleic acid (0.1\% C16:1), unsaturated oleic acid $(22.7 \% \mathrm{C} 18: 1)$, triunsaturated linolenic acid $(0.5 \% \mathrm{C} 18: 3)$ and saturated palmitic and stearic acids, respectively $(6.9 \% \mathrm{C} 16: 0)$ and $(3.9 \% \mathrm{C} 18: 0)$. Then, GSO had 4.75 double bonds per triglyceride.

${ }^{1} \mathrm{H}$ NMR (300 MHz, $\mathrm{CDCl}_{3}$ ), $\delta=0.79-0.88(9 \mathrm{H}, \mathrm{H}-20$ and $\mathrm{H}-$ $20^{\prime}$ ), $1.16-1.30$ (52.36 H, H-6 to H-9, H-14 to H-19, H-6' to
$\mathrm{H}-9^{\prime}, \mathrm{H}-17^{\prime}$ to $\left.\mathrm{H}-19^{\prime}\right), 1.6$ (6.9 $\mathrm{H}, \mathrm{H}-5$ and $\mathrm{H}-5^{\prime}$ ) 1.922.07(10.75 $\left.\mathrm{H}-\mathrm{CH}_{2}-\mathrm{CH}=\mathrm{CH}-\right), 2.24-2.37(\mathrm{t}, 5.96 \mathrm{H}, \mathrm{H}-4$ and $\mathrm{H}-4^{\prime},{ }^{3} \mathrm{~J}=7.5 \mathrm{~Hz}$ ), 2.74-2.78 (t, $3.73 \mathrm{H}, \mathrm{H}-13^{\prime},{ }^{3} \mathrm{~J}=5.7$ $\mathrm{Hz},{ }^{3} \mathrm{~J}=6 \mathrm{~Hz}$ ), 4.11-4.17 (dd, $2 \mathrm{H}, \mathrm{H}-2,{ }^{2} \mathrm{~J}=11.7 \mathrm{~Hz},{ }^{3} \mathrm{~J}=$ $\left.5.7 \mathrm{~Hz},{ }^{3} \mathrm{~J}=6 \mathrm{~Hz}\right), 4.26-4.32\left(\mathrm{dd}, 2 \mathrm{H}, \mathrm{H}-2^{\prime},{ }^{2} \mathrm{~J}=12 \mathrm{~Hz},{ }^{3} \mathrm{~J}=\right.$ $4.2 \mathrm{~Hz}), 5.21-5.42(\mathrm{~m}, 10.49 \mathrm{H}, \mathrm{H}-1, \mathrm{CH}=\mathrm{CH})$.

${ }^{13} \mathrm{C}$ NMR (75.47 $\mathrm{MHz}, \mathrm{CDCl}_{3}$ ), $\delta=13.98\left(\mathrm{C}-20\right.$ and $\left.\mathrm{C}-20^{\prime}\right)$, 22.49-22.6 (C-19 and C-19'), 24.74 (C-5 and C-5'), 25.54 (C13'), 27 (C-10, C-13, C10' and C-16'), 28.95-29.68 (C-6 to C9, $\mathrm{C}-14$ to $\mathrm{C}-17, \mathrm{C}-6^{\prime}$ to $\mathrm{C}-9^{\prime}$ and $\mathrm{C}-17^{\prime}$ ), 31.44-31.8 (C-18 and $\mathrm{C}-18^{\prime}$ ) 33.9-34.07 (C-4 and C-4'), 61.9 (C-2), 68.8 (C-1), 127.8-130.05 (C-11, C-12, C-11', C-12', C-14', and $\mathrm{C} 15^{\prime}$ ), 172.64-173.04 (C-3 and C-3').

FTIR $\left(\mathrm{cm}^{-1}\right): 3009(=\mathrm{CH}), 2923$ and 2854 (C-H), 1743 $\left(\mathrm{C}=\mathrm{O}_{\text {ester }}\right), 1653(\mathrm{C}=\mathrm{C}), 1464\left(\mathrm{CH}_{2}\right.$ scissoring $), 1377,1159$ (C-0), 1098, 722.

A number followed by (') corresponds to linoleic chain whereas a number without punctuation corresponds to oleic chain.

\section{Synthesis of Aminated GSO: AGSO}

First GSO, CAHC (3 equiv per double bonds present on triglyceride), and 0-0.1 equiv of DMPA (also per double bonds present on triglyceride), were dissolved in minimal amount of cosolvents: 1,4-dioxane/ethanol $(70 / 30 \mathrm{v} / \mathrm{v})$ required to dissolve all components. The mixture could be slightly heated if necessary $\left(T<40^{\circ} \mathrm{C}\right)$. Reactions were performed in photoreactor (Scheme 1) where UV lamp was placed in a water cooled (around $20{ }^{\circ} \mathrm{C}$ ) jacket made in Pyrex, itself immersed in a larger tube containing raw materials. Irradiation was carried out during a time ranging from 8 to $96 \mathrm{hrs}$. For low conversion level, ethanol was evaporated and organic phase was washed with $\mathrm{Na}_{2} \mathrm{CO}_{3}$ saturated solution and left at $-20{ }^{\circ} \mathrm{C}$ : solid appeared and was removed by filtration; washing treatment was repeated till no more precipitation was observed. For reaction characterized by high conversion level, solvents were replaced by chloroform, the organic phase was then washed as described previously. As CAHC was eliminated, organic phase was dried over $\mathrm{MgSO}_{4}$ and solvent was removed by vacuum evaporation.

The calculation of AGSO molecular weight: $M=794+96-$ $4.75 \times(1-\rho) \times 2-4.75 \times \rho+4.75 \times \rho \times 76$ where $\rho$ was the conversion. In the case of $87 \%$ conversion the molecular weight is $1198.7 \mathrm{~g} / \mathrm{mol}$.

AGSO had an amine equivalent weight of $290 \mathrm{~g} \mathrm{equiv}^{-1}$ for $87 \%$ conversion.

${ }^{1} \mathrm{H}$ NMR (300 MHz, $\mathrm{CDCl}_{3}$ ), $\delta=0.74-0.97$ (9 H, H-20), 0.971.80 (95.54 H, H-5 to H-19), 1.89-2.06 (0.76 H, H-10, and H13), $2.16-2.31\left(\mathrm{t}, 6.20 \mathrm{H}, \mathrm{H}-4,{ }^{3} \mathrm{~J}=7.5 \mathrm{~Hz}\right), 2.32-2.69(\mathrm{~m}$, $8.71 \mathrm{H}, \mathrm{H}-12^{\prime}, \mathrm{H}-15^{\prime}$, and H-21), 2.69-2.96 (t, $6.80 \mathrm{H}, \mathrm{H}-22$, ${ }^{3} \mathrm{~J}=4.8 \mathrm{~Hz},{ }^{3} \mathrm{~J}=6.3 \mathrm{~Hz}$ ), 4.03-4.34 (m, 3.34 H, H-2), 5.175.33 (m, $0.93 \mathrm{H}, \mathrm{H}-1), 5.36$ (0.04 H, H-11, and H-12).

${ }^{13} \mathrm{C}$ NMR (75.47 MHz, $\mathrm{CDCl}_{3}$ ), $\delta=14.08$ (C-20), 22.59 (C19), 24.77 (C-5), 26.35-26.95 (C-10 and C-13), 28.8-31.90 (C-6 to C-11, C-14 to C-18), 33.85-34.24 (C-4), 34.34-35.20 


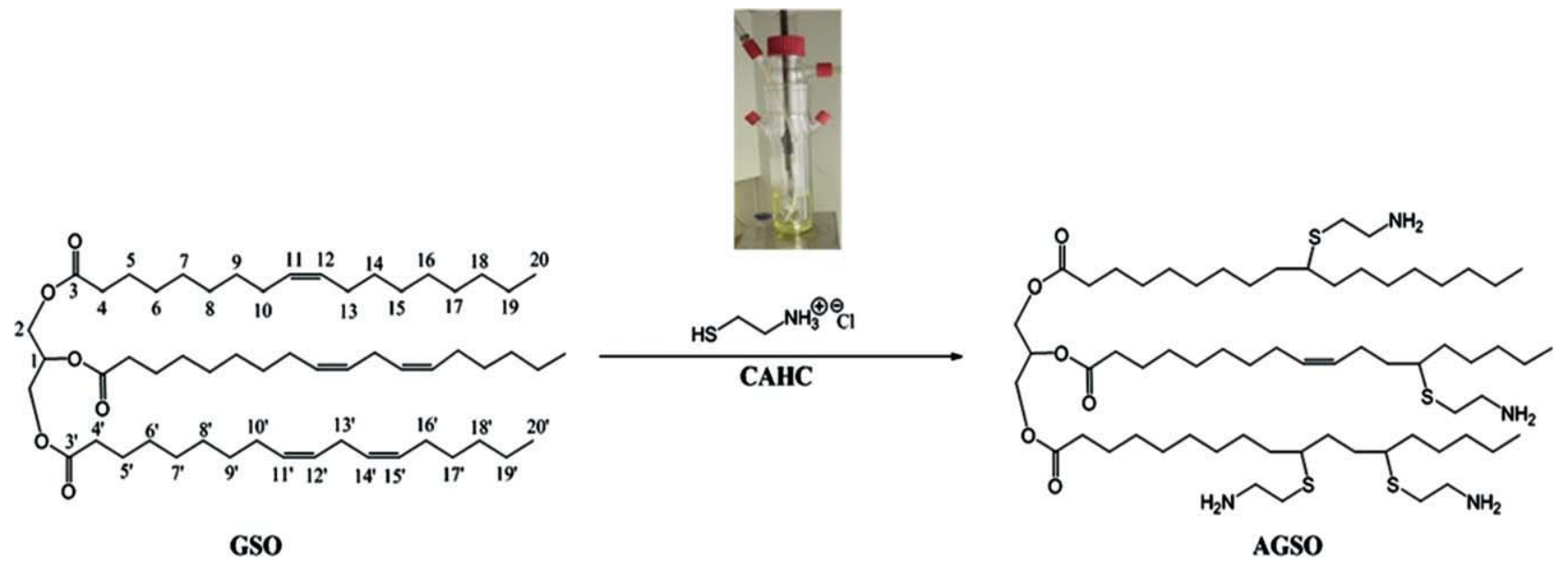

SCHEME 1 Amination of GSO using CAHC by UV initiated thiol-ene coupling.

(C-21), 41.50 (C-22), 45.77 (C-12' and C-15'), 62.00 (C-2), 68.81 (C-1), 126.97-130.71 (C-11 and C-12), 173.2 and $172.7(\mathrm{C}-3)$.

FTIR $\left(\mathrm{cm}^{-1}\right): 3288(\mathrm{~N}-\mathrm{H}), 2923$ and $2853(\mathrm{C}-\mathrm{H}), 1736$ $\left(\mathrm{C}=\mathrm{O}_{\mathrm{ester}}\right), 1645$ and $1546(\mathrm{~N}-\mathrm{H}), 1455\left(\mathrm{CH}_{2}\right.$ scissoring), 1377, 1175 (C-0), 743.

\section{Characterization of ELO}

Linseed oil contains predominantly the triunsaturated linolenic acid (47.4\% C18:3) in its structure. In addition, grape seed oil contains unsaturated oleic (19.0\% C18:1), diunsaturated linoleic $(24.1 \% \mathrm{C} 18: 2)$ and saturated palmitic and stearic $(6.0 \% \mathrm{C} 16: 0)$ and $(2.5 \% \mathrm{C} 18: 0)$, respectively and others 1.0. ${ }^{44}$ Then, linseed oil can be considered as having 6 carbon double bonds per triglyceride.

${ }^{1} \mathrm{H}$ NMR (300 MHz, $\mathrm{CDCl}_{3}$ ), $\delta=0.78-0.93$ (4.54 H, H-20), 1$1.23\left(4,42 \mathrm{H}, \mathrm{H}-20^{\prime}\right.$, and $\left.\mathrm{H}-20^{\prime \prime}\right)$ 1.23-1.67 (59.69 $\mathrm{H}, \mathrm{CH}_{2}$ ), 2.23-2.35 (t, $5.78 \mathrm{H}, \mathrm{H}-4, \mathrm{H}-4^{\prime}$, and $\mathrm{H}-4^{\prime \prime},{ }^{3} \mathrm{~J}=7.5 \mathrm{~Hz}$ ), 2.88$3.2\left(\mathrm{~m}, 10.53 \mathrm{H}, \mathrm{CH}\right.$ epoxy), 4.06-4.15 (dd, $2 \mathrm{H}, \mathrm{H}-2,{ }^{2} \mathrm{~J}=$ $11.7 \mathrm{~Hz},{ }^{3} \mathrm{~J}=6 \mathrm{~Hz}$ ), 4.25-4.34 (dd, $2 \mathrm{H}, \mathrm{H}-2^{\prime},{ }^{2} \mathrm{~J}=11.7 \mathrm{~Hz},{ }^{3} \mathrm{~J}$ $=4.2 \mathrm{~Hz}), 5.19-5.29(\mathrm{~m}, 0.96 \mathrm{H}, \mathrm{H}-1), 5.55-5.72(\mathrm{~m}, 0.27$, $\mathrm{CH}=\mathrm{CH}$ ).

A number followed by (') or (") corresponds to a fatty chain bearing two or one epoxy groups, respectively. A number without punctuation corresponds to a fatty chain bearing three epoxy groups.

${ }^{13} \mathrm{C}$ NMR (75.47 $\mathrm{MHz}, \mathrm{CDCl}_{3}$ ), $\delta=10.5$ and 14.1 (C-20, C$20^{\prime}$, and $\left.\mathrm{C} 20^{\prime \prime}\right), 21.15$ and $22.6\left(\mathrm{C}-19, \mathrm{C}-19^{\prime}\right.$, and $\left.\mathrm{C}-19^{\prime \prime}\right)$, 24.7 (C-5, C-5', and C-5"), 26.8-27.7 ( $\mathrm{CH}_{2}$-epoxy and $\left.\mathrm{CH}_{2}-\mathrm{CH}=\mathrm{CH}-\right), 28.9-29.6\left(\mathrm{CH}_{2}\right), 31.55-31.8\left(\mathrm{C}-18^{\prime}\right.$ and C$18^{\prime \prime}$ ), 33.9-34.07 (C-4, C-4', and C-4"), 53.9-58.8 (CH epoxy), $62\left(\mathrm{C}-2\right.$ and $\left.\mathrm{C}-2^{\prime}\right), 68.8(\mathrm{C}-1), 127(\mathrm{CH}=\mathrm{CH}), 172.7-173.2(\mathrm{C}-$ 3 and $\left.\mathrm{C}-3^{\prime}\right)$.

FTIR ( $\left.\mathrm{cm}^{-1}\right)$ : 2930 and 2858 (C-H $\left.\mathrm{H}_{\text {stretching }}\right), 1739$ ( $\left.\mathrm{C}=\mathrm{O}_{\text {ester stretching }}\right)$, $1457\left(\mathrm{CH}_{2}\right.$ bending $), 1391\left(\mathrm{CH}_{3}\right.$ bending $), 1248,1164,1117$ ( $\mathrm{C}-\mathrm{O}_{\text {stretching }}$ ), $821\left(\mathrm{C}-\mathrm{O}_{\text {epoxide group }}\right), 740\left(\mathrm{CH}_{2}\right.$ rocking $)$.

By ${ }^{1} \mathrm{H}$ NMR spectroscopy, the signal located at $2.88-3.2 \mathrm{ppm}$ was attributed to the epoxy groups and that located at 5.55-
$5.72 \mathrm{ppm}$ was associated to the residual ethylenic protons. The epoxidation percentage of ELO was calculated from the ratio of the associated integrals to be close to $98 \%$. The number of epoxy groups per ELO molecule (5.3) was evaluated from the integration of the signals associated to the epoxy groups (2.88-3.2 ppm) and the ending methyl groups at $0.78-0.93$ and $1.00-1.23 \mathrm{ppm}$. Finally the molecular weight of ELO was $965 \mathrm{~g} / \mathrm{mol}$ and the epoxide equivalent weight was $181.9 \mathrm{~g} \mathrm{equiv}^{-1}$.

\section{RESULTS AND DISCUSSION}

\section{Synthesis of Aminated Vegetable Oil by UV Initiated Thiol-ene Coupling}

Among the raw renewable resources (lignin, proteins, chitosan...) plant oils rose interest due to their vast abundance and high functionality. The reactivity of the double bonds of fatty chains was widely explored in the design of bio-based materials. ${ }^{9,10}$ Herein the synthesis of bio-based amine from vegetable oil was investigated even if several synthetic methods were already developed via aziridine, ${ }^{18}$ hydrazine, ${ }^{20,21}$ nitrile. $^{23}$ In this context, thiol-ene chemistry (TEC) represents a direct and efficient method for the introduction of amine group into vegetable oil. The reaction can be performed in air without the complication of competing side reactions with oxygen. We investigated the TEC of vegetable oil using the thiol group of cysteamine hydrochloride CAHC. This reagent is more stable than cysteamine as previously shown. ${ }^{45}$ Grape seed oil GSO was chosen as oil model. By Gas Chromatography technique the composition in various fatty chains was determined.

TEC can be performed under thermal initiation or UV light irradiation. ${ }^{46}$ Nevertheless in preliminary study the thermal degradation of crude GSO was observed by Thin Layer Chromatography (TLC) as shown in Figure 1. The thermal degradation of triacylglycerols (ATG)s into diacylglycerols (DAG)s and others fatty compounds were detected after 4 days at $80{ }^{\circ} \mathrm{C}$. Contrary GSO seems intact after $8 \mathrm{hrs}$ of UV radiation exposure and justified the employment of UV light irradiation in TEC reaction of GSO. 


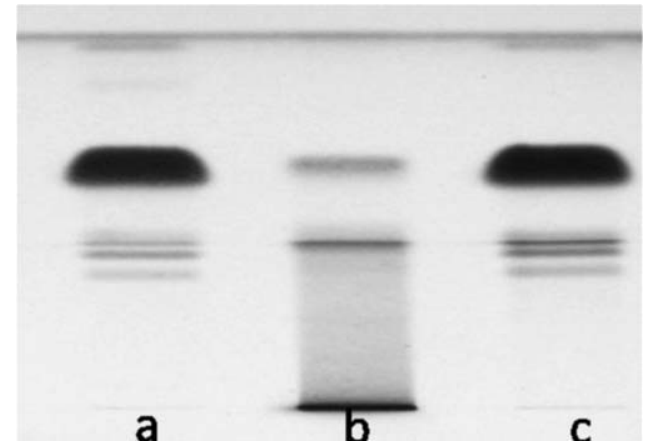

FIGURE 1 Thin layer chromatography (TLC) analysis of (a) crude GSO, (b) GSO after a heating at $80{ }^{\circ} \mathrm{C}$ for 4 days, and (c) GSO after insolation for $8 \mathrm{hrs}$.

As depicted in Scheme 1, the novel aminated-vegetable oil AGSO was prepared by the reaction of GSO with CAHC in 1,4-dioxane-EtOH $(70 / 30 \mathrm{v} / \mathrm{v})$ at room temperature for 8 hr. UV light was used to promote this reaction with the aid of a suitable photoinitiator: 2,2-dimethoxy-2-phenylacetophenone (DMPA). The basic reactor consists of an annular cylindrical space in which the reacting liquid is maintained and stirred. The reaction volume is illuminated from the center by an axially mounted fluorescent type UV lamp. The operating characteristics of this lamp, a HPK $125 \mathrm{~W}$ high-pressure mercury vapor lamp of Heraeaus Noblelight, have been noted. The lamp provides maximum energy at a wavelength of $365 \mathrm{~nm}$, with substantial radiations also at $435,313,253$, and $404 \mathrm{~nm}$. The entire reactor was placed within a darkened hood to isolate the vessel from stray light. All reactant materials were stored at $25{ }^{\circ} \mathrm{C}$ to avoid any thermal degradation.

In TEC, the initial product formed upon exposure of the labile sulfur-hydrogen bond of CAHC to UV irradiation is the thiyl radical. The latter adds on the unsaturated GSO to form a carbon-atom-centered radical which transfers a hydrogen atom from another thiol reactant to give the sulfide product. The addition of $\mathrm{RS}^{\circ}$ radical on unsaturated vegetable oil GSO was estimated by the integration of $-\mathrm{S}-\mathrm{CH}_{2}-\mathrm{CH}_{2}-\mathrm{NH}_{2}$ $\left(\mathrm{H}_{21}\right)$ at 2.42-2.69 ppm and $-\mathrm{S}-\mathrm{CH}_{2}-\mathrm{CH}_{2}-\mathrm{NH}_{2}\left(\mathrm{H}_{22}\right)$ at 2.69-2.96 ppm by ${ }^{1} \mathrm{H}$ NMR spectroscopy as shown in Table 1. Another calculation consists in the integration of the disappearance of the signals associated to ethylenic protons knowing that the ethylenic protons overlapped the $\mathrm{CH}$ of glyceryl part at 5.21-5.42 ppm. The difference of conversion values could be explained by the consumption of $\mathrm{C}=\mathrm{C}$ bonds in side-reactions. Diels-Alder reactions and intra- and intertriacylglycerol bridges ${ }^{47,48}$ seemed unlikely because they usually occurred at elevated temperature. As already observed in previous studies the competition between $\mathrm{H}^{\circ}$ and $\mathrm{RS}^{\circ}$ radicals could occur. If the addition of $\mathrm{H}^{\circ}$ on $\mathrm{C}=\mathrm{C}$ was promoted, unsaturated by-product was observed with consumption of $\mathrm{C}=\mathrm{C}$ bond and without addition of thiol. ${ }^{31}$ Other side-reactions could be mentioned such as the oligomerization $^{33}$ and the reaction of alkylperoxy radical on enes. ${ }^{49}$ From these remarks, the best way to evaluate the conversion was the integration of the $\mathrm{RS}$ radical on $\mathrm{C}=\mathrm{C}$ signal.

To optimize the reaction conditions, four reaction parameters were varied. The parameters were the nature and quantity of photoinitiator, the reaction time and concentration of the reaction mixture. It was widely demonstrated the influence of $[\mathrm{C}=\mathrm{C}] /[\mathrm{RSH}]$ ratio. $^{50}$ In fact, an amount of thiol reactant was consumed in side-reaction where disulfide bridges were yielded. The acidity of the thiol influenced the equilibrium thiol-disulfide. For instance the ratio of disulfide bond was 0.3 and $1-2 \%$ for methyl linoleate and oleic acid, respectively. ${ }^{51}$ In our system, a preliminary study revealed the optimum $[\mathrm{C}=\mathrm{C}] /[\mathrm{RSH}]$ ratio of $3 .^{50}$ The reaction occurred in presence of solvent due to the insolubility of CAHC in GSO. The best experimental protocol was obtained with 1,4dioxane-EtOH $(70 / 30 \mathrm{v} / \mathrm{v})$ that doesn't interfere with UV mercury lamp. The UV initiated TEC between CAHC and GSO could be occurred without photoinitiator. The reaction was very slow with $22 \%$ and $65 \%$ conversion after 24 and 72 hrs, respectively (entries 5 and 6 Table 1). We noted that $22 \%$ conversion was reached after $24 \mathrm{hrs}$ without photoinitiator but only after $8 \mathrm{hr}$ in presence of 0.01 eq of DMPA (entries 1 and 5 Table 1). Whatever the photoinitiator the cleavage of the $\mathrm{S}-\mathrm{H}$ bond was dominant compared to that of the $\mathrm{C}=\mathrm{C}$ bond. Thus, the direct hydrogen abstraction by the triplet photoinitiator from thiol promotes TEC reaction. ${ }^{49}$ The influence of the type of photoinitiator on the TEC was already demonstrated. The Type I of photoinitiator is more efficient than the one with Type II photoinitiator. In the latter case the reactive radicals are produced by a bimolecular reaction with a lower quantum yield. When using Type I photoinitiators, the transient excited states (singulet and triplet) have very short lifetimes, thus preventing any quenching by the thiol. ${ }^{52}$ Therefore the use of one-component photoinitiator systems of type I namely DMPA (benzoin ether) and TPO (benzoyl phosphine oxide) was justified (entries 3 and 7 Table 1). Both the cleavage process in the triplet state is very fast compared to that of some related structures in our experimental conditions $(\lambda=365 \mathrm{~nm})$. The kinetic of

TABLE 1 Results of UV Initiated Thiol-ene Coupling Between CAHC and GSO

\begin{tabular}{llll}
\hline Entry & DMPA (eq) & $t(\mathrm{~h})$ & $\rho(\%)^{\mathrm{a}} \rho(\%)^{\mathrm{b}}$ \\
1 & 0.01 & 8 & $41 / 22$ \\
$2^{\mathrm{c}}$ & 0.01 & 8 & $17 / 20$ \\
3 & 0.1 & 8 & $100 / 87$ \\
4 & 0.01 & 24 & $25 / 23$ \\
5 & - & 24 & $23 / 22$ \\
6 & - & 72 & $62 / 65$ \\
$7^{\mathrm{d}}$ & 0.1 & 8 & $86 / 66$
\end{tabular}

Experimental conditions: cosolvent: 1,4-dioxane-EtOH $(70 / 30 \mathrm{v} / \mathrm{v})$, $[\mathrm{C}=\mathrm{C}] /[\mathrm{RSH}]=[\mathrm{GSO}] /[\mathrm{CAHC}]=3,[\mathrm{GSO}]=0.4 \mathrm{M}$.

${ }^{\text {a }}$ Conversion calculated by disappearance of ethylenic protons.

${ }^{b}$ Conversion calculated by appearance of $\mathrm{H}_{21}$ and $\mathrm{H}_{22}$.

${ }^{c}$ Concentration in $\mathrm{C}=\mathrm{C}$ of GSO: $0.7 \mathrm{M}$.

d TPO initiator replaced DMPA. 

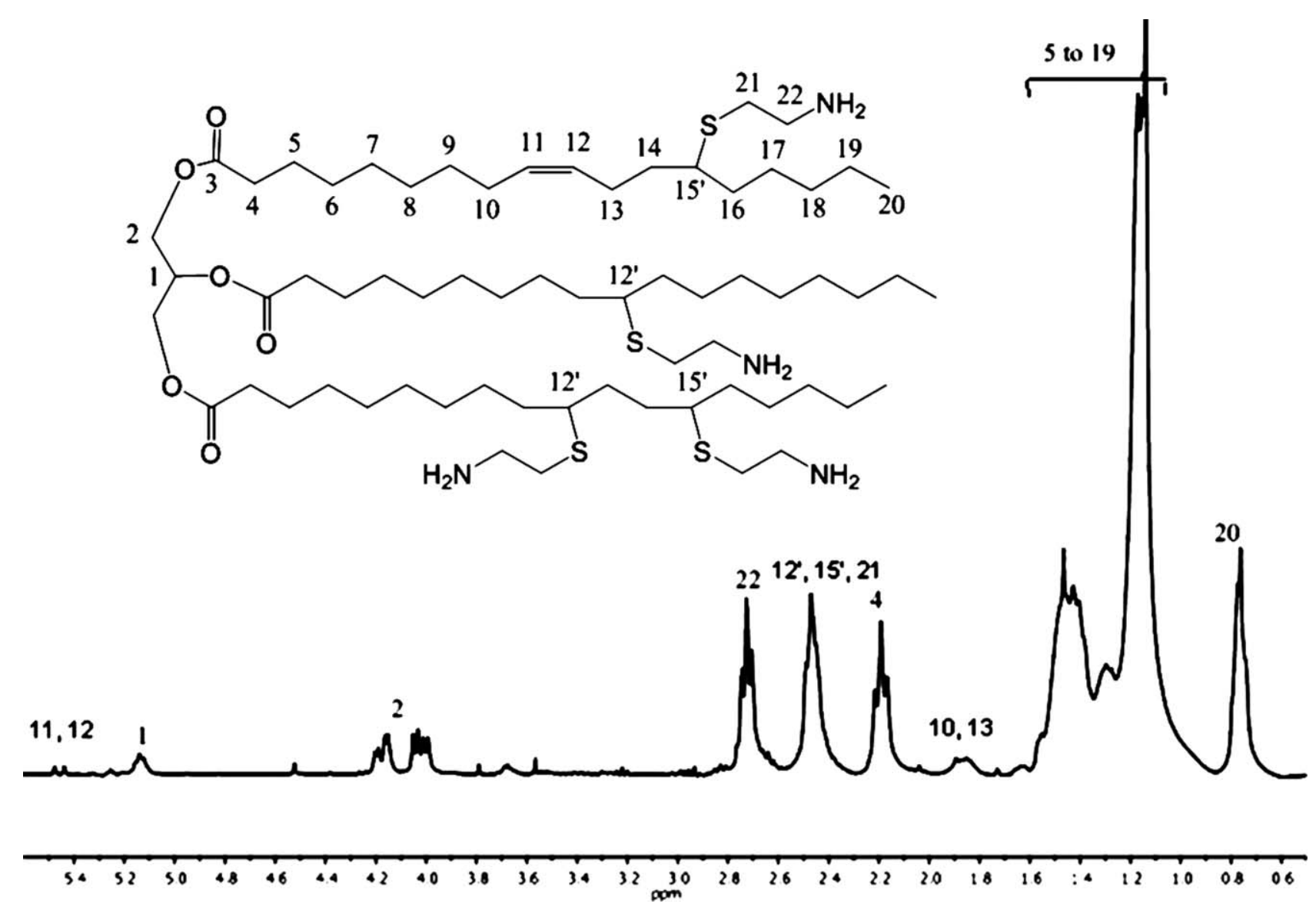

FIGURE $2{ }^{1} \mathrm{H}$ NMR spectrum of AGSO in $\mathrm{CDCl}_{3}$.

the DMPA and TPO cleavage process were similar with a triplet state lifetime of 0.25 and 0.12 ns, and a quantum yields dissociation of 0.95 and 0.7 , respectively. ${ }^{53}$ DMPA was more efficient as compared to TPO with $87 \%$ and $66 \%$ conversion, respectively. The difference of TEC results could be explained by the difference of reactivity of their radicals. The phosphonyl radicals produced from TPO may be more reactive towards enes thus lowering the reaction efficiency with thiols and disadvantaged the TEC reaction. The influence of the concentration of the reaction mixture was studied but none significant consequence was noted. Indeed, a conversion of $22 \%$ and $20 \%$ were observed for 0.4 and $0.7 \mathrm{M}$, respectively (entries 1 and 2 Table 1). Subsequently the reaction proceeded at $0.4 \mathrm{M}$ because some problems of reproducibility were observed when the reaction mixture was more concentrated. The phenomenon was probably due to a limit of solubility between CAHC and GSO. The importance of the quantity of DMPA was visible when the entries 1 and 3 of the Table 1 were compared. An enhancement from 0.01 to 0.1 equivalent in DMPA increased the conversion from 22 to $87 \%$. We also noted that the extension of the reaction with low DMPA equivalent does not have impact on the conversion: 22 and $23 \%$ after 8 and $24 \mathrm{hr}$, respectively (entries 1 and 4 Table 1).

In conclusion, UV initiated TEC between CAHC and GSO can be tuned by varying the nature and quantity of photoinitia- tor, reaction time and concentration of the reaction mixture. In optimum experimental conditions a quantitative consumption of the double bonds and $87 \%$ conversion of CAHC were observed.

\section{Chemical Characterization of AGSO}

The AGSO structure was confirmed by FTIR, LC-MS, ${ }^{1} \mathrm{H}$ NMR, and ${ }^{13} \mathrm{C}$ NMR techniques. Firstly in the ${ }^{1} \mathrm{H}$ NMR spectrum appeared some characteristic signals: $\mathrm{CH}_{2}-\mathrm{S}\left(\mathrm{H}_{21}\right)$ and $\mathrm{CH}_{2}-\mathrm{N}\left(\mathrm{H}_{22}\right)$ at 2.42-2.69 ppm and 2.69-2.96 ppm, respectively (Fig. 2). During the TEC using CAHC, no hydrolysis of glycerol bridge in GSO was detected by the integration of $\mathrm{H}_{1}$ corresponding to glyceryl part related to the ending methyl group of fatty chains $\left(\mathrm{H}_{20}\right)$ at $0.74-0.97 \mathrm{ppm}$. The calculation of the average amine units per molecule could be evaluated. For instance 4.1 amine units per molecule were estimated in the case of entry 3 of Table 1. By integrating of the signals corresponding to $\mathrm{CH}_{2}-\mathrm{S}$ at 2.42-2.69 ppm and the ending methyl groups at $0.74-0.97 \mathrm{ppm}$, the average molar weight of AGSO was estimated to $1200 \mathrm{~g} / \mathrm{mol}$.

Thanks to DEPT-135 NMR sequence the addition of CAHC on GSO was demonstrated with the appearance of a signal at 45.77 ppm which corresponded to $\mathrm{CH}-\mathrm{S}\left(\mathrm{C}_{12^{\prime}}\right)$ as depicted in Figure 3. In this ${ }^{13} \mathrm{C}$ NMR experiment the residual $\mathrm{C}=\mathrm{C}$ were observed in the region of $130 \mathrm{ppm}$ as well as $\mathrm{CH}$ of glyceryl part $\left(\mathrm{C}_{1}\right)$ at $68.81 \mathrm{ppm}$. The $\mathrm{CH}_{2}$ of cysteamine part 

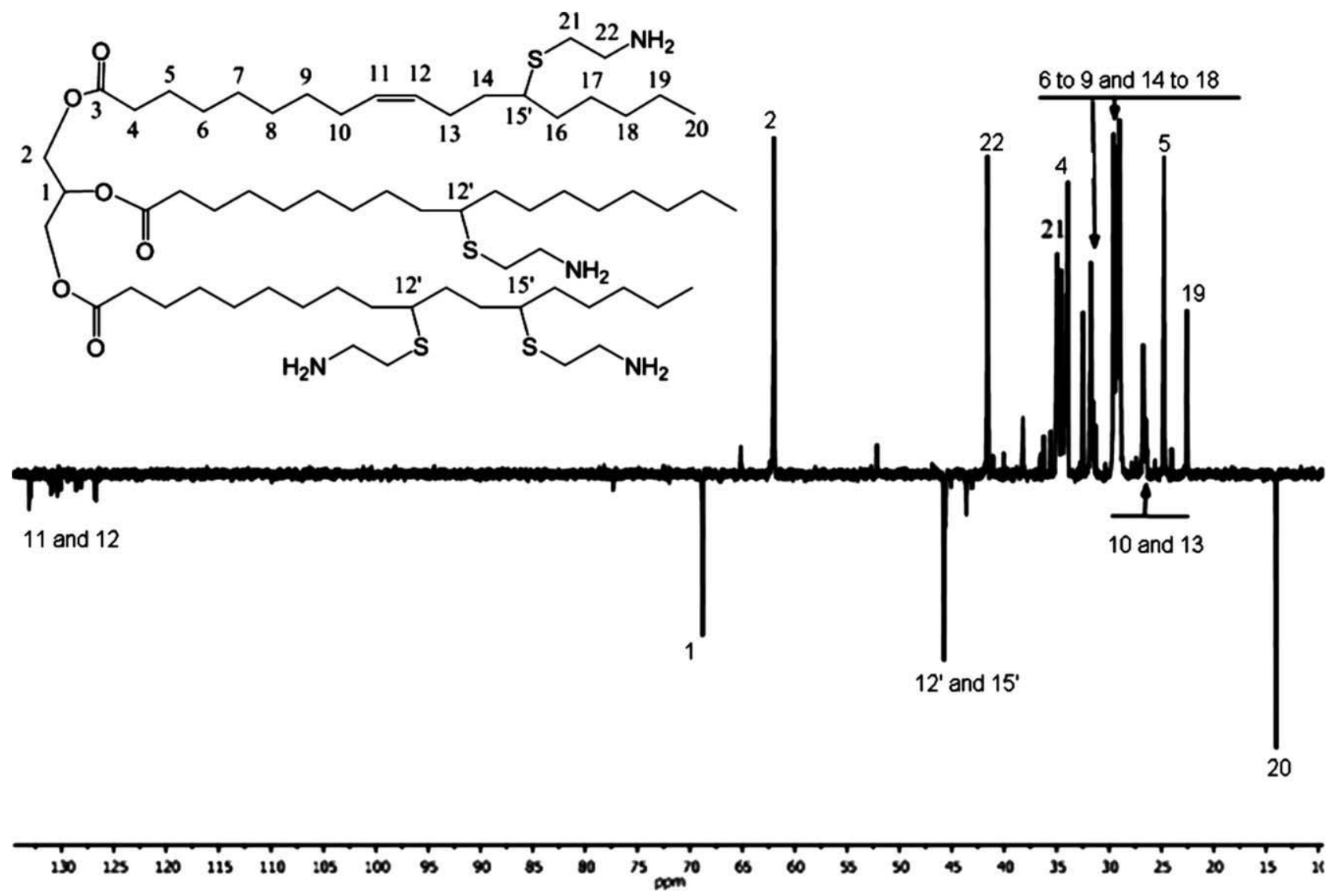

FIGURE 3 DEPT-135 NMR spectrum of AGSO in $\mathrm{CDCl}_{3}$.

$\left(\mathrm{C}_{21}\right.$ and $\left.\mathrm{C}_{22}\right)$ were located at $34.34-35.20$ and $41.50 \mathrm{ppm}$ while those of $\mathrm{CAHC}$ at 22.2 and $42.8 \mathrm{ppm}$. The latters revealed residual CAHC.

In our study, some NMR results were confirmed by LC-MS technique (see Supporting Information). For instance the efficiency of the purification was revealed since no trace of CAHC was observed. The disulfide product corresponding to the coupling between two CAHC reactants was also detected at $153 \mathrm{~g} \mathrm{~mol}^{-1}$. Thanks to LC-MS technique triacylglycerides (TAG)s, diacylglycerides (DAG)s, and fatty acids (FA)s could be also identified and more detailed informations than NMR technique could be given. For instance, no original TAG, DAG and FA were observed. The more functionalized AGSO has got six amine units per triglyceride at $1342.2 \mathrm{~g} \mathrm{~mol}^{-1}$. Five-, four-, and three-amine units per AGSO molecule were also detected at 1267.1, 1192.1, and $1117.1 \mathrm{~g} \mathrm{~mol}^{-1}$, respectively. Finally some TAG, DAG and FA with residual $\mathrm{C}=\mathrm{C}$ bond were detected at $1115.1,1039.8$ and $954.8 \mathrm{~g} \mathrm{~mol}^{-1}$ according to ${ }^{1} \mathrm{H}$ and ${ }^{13} \mathrm{C}$ NMR analysis.

GSO and AGSO were also characterized by FTIR spectroscopy. In particular, the amination of GSO can be monitored by the appearance of characteristic absorbance bands in the spectrum of AGSO as evidenced in Figure 4. The band centered at $3314 \mathrm{~cm}^{-1}$ is specific of $\mathrm{N}-\mathrm{H}$ stretching while those detected at $1653 \mathrm{~cm}^{-1}$ and $1552 \mathrm{~cm}^{-1}$ are related to the $\mathrm{N}-\mathrm{H}$ bending. Moreover, the $\mathrm{C}=\mathrm{C}$ band at $3009 \mathrm{~cm}^{-1}$ pres- ent in GSO spectrum disappeared in aminated vegetable oil AGSO spectrum. The characteristic residual band of mercaptan reactant CAHC was not observed at $2500 \mathrm{~cm}^{-1}$.

Viscosimetric Study of GSO and AGSO

Besides the chemical analyses described previously, the progressive amination of the GSO can also be followed by viscosimetry. Figure 5 depicts as an example the influence of the temperature on the viscosity of different samples with specific amination percentages. Whatever the fluid analyzed, the temperature increased from 20 to $150{ }^{\circ} \mathrm{C}$ producing a reduction of the viscosity. At a given temperature, the lowest

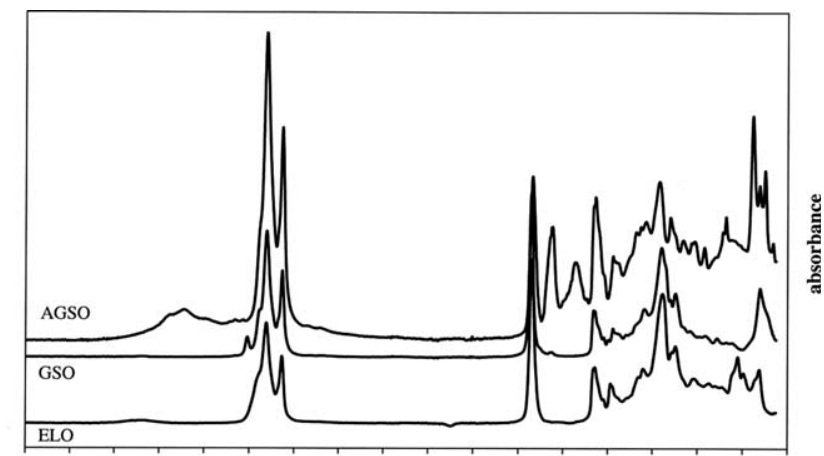

4000380036003400320030002800260024002200200018001600140012001000800600 wavenumber $\left(\mathrm{cm}^{-1}\right)$

FIGURE 4 FTIR spectra of GSO, ELO, and AGSO. 


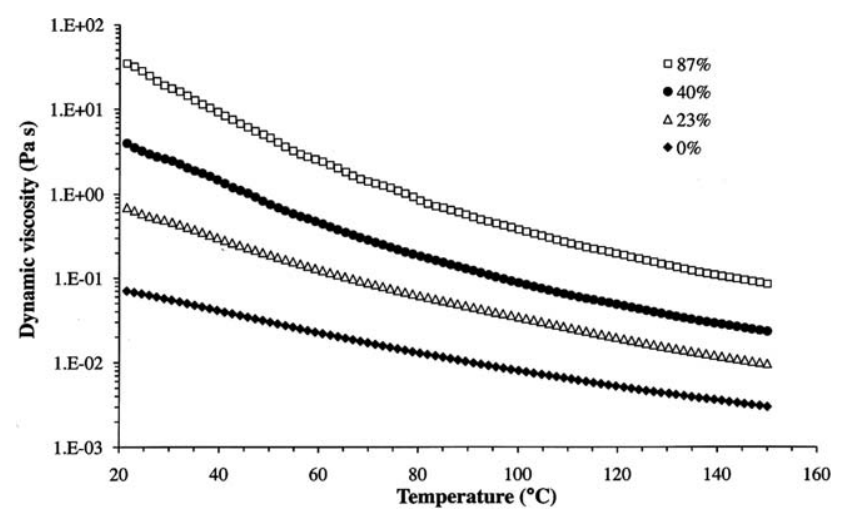

FIGURE 5 Influence of amination percentage on the temperature dependence of the viscosity of GSO.

value was always observed with GSO while AGSO viscosity seemed to be directly proportional to the amination degree. The evolution was quite important since at the ambient, the viscosity of the highly aminated oil was measured to be 500 times greater than the original GSO. This latter dependence could be interpreted as being the consequence of two combined effects: the grafting of cysteamine segments on fatty chains was expected to produce a reduction of the molecular mobility of the triglyceride chains and at the same time an increase of their hydrodynamic drag due to steric effects.

\section{Study of the Reaction Between AGSO and ELO}

It is well known that epoxy resins may be 'cured' by many types of hardeners, among which amines retain a prominent position due to their higher reactivity in comparison with anhydrides systems. In addition, amine cured epoxy resins also present an enhanced environmental (hydrolytic) stability. In this context, the use of AGSO as a hardener for epoxy resin seems worthy to be explored. Considering that an amine can react with two epoxy groups and taking into account the respective quantity of these chemical functions, respectively in AGSO and ELO, both oils were mixed in stoichiometric proportions at room temperature (Scheme 2).

\section{Calorimetric Experiment}

First experiment undertaken on the AGSO-ELO mixture consisted to investigate by DSC if the system was able to undergo a crosslinking reaction. Indeed, the formation of a 3D polymeric network is an exothermic phenomenon that can logically be detected by calorimetry provided that the corresponding enthalpy is high enough (Supporting Information). Figure 1 shows the result of the analysis registered at $10{ }^{\circ} \mathrm{C} / \mathrm{min}$ for the system produced from ELO with AGSO (with $87 \%$ of $\mathrm{NH}_{2}$ grafting). One can note the presence of an exothermic peak from 100 to $240{ }^{\circ} \mathrm{C}$ and with a maximum located at $200{ }^{\circ} \mathrm{C}$. By integration of this peak, the corresponding crosslinking enthalpy was evaluated to be close to $50 \mathrm{~J} / \mathrm{g}$. This value can appear quite low if it is compared to the reaction enthalpy currently encountered with DGEBAamine system $^{54}$ ( $\Delta H \sim 500 \mathrm{~J} / \mathrm{g}$ ). Actually, oil-based epoxy resin cured with diamine generally present crosslinking energy close to $100 \mathrm{~J} / \mathrm{g}^{55}$

\section{Kinetic Rheological Analyses}

To go further in the characterization of the crosslinking process of the AGSO-ELO system, rheological measurements were undertaken on the same reactive mixture at different fixed temperatures. Two examples of results obtained, respectively at 100 and $120{ }^{\circ} \mathrm{C}$ are plotted in Figure 6. These temperatures were arbitrarily chosen at the beginning of the polymerization domain because they were judged more convenient for the production of a cured polymer of good quality. Indeed, if a high curing temperature often permits a fast crosslinking process, it can also brings about the formation of many structural defects in the polymer network such as dangling chains that are not elastic active.
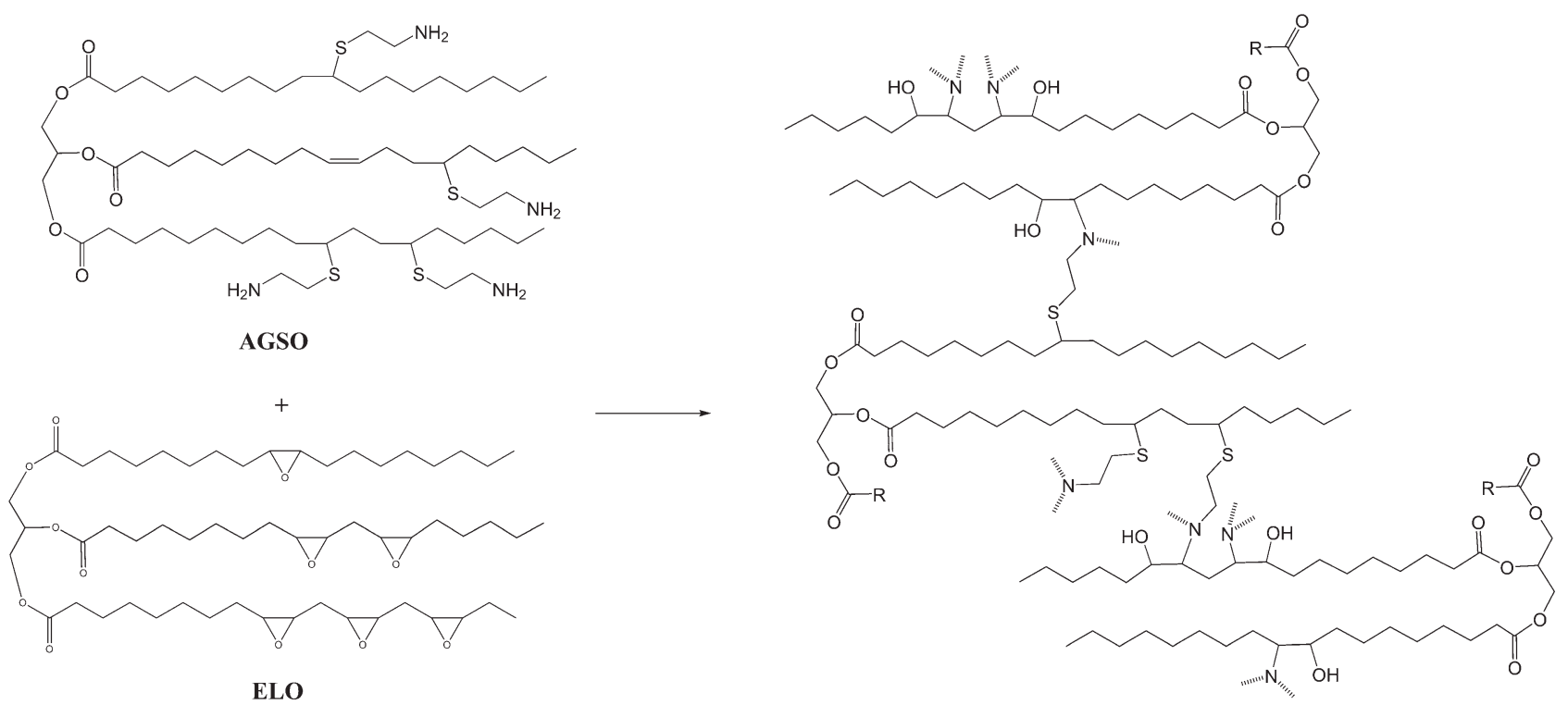

SCHEME 2 Crosslinking reaction between ELO and AGSO. 


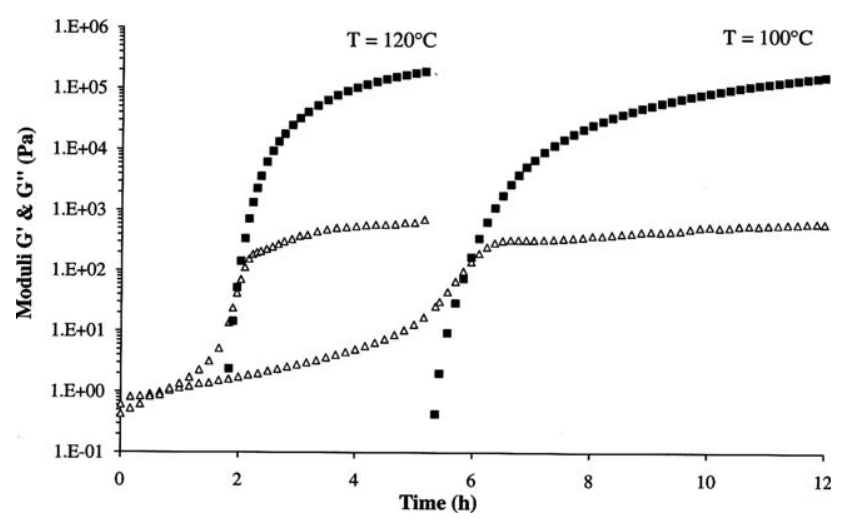

FIGURE 6 Rheological analysis of the isothermal curing of the AGSO-ELO mixture for two temperatures and with $G^{\prime}(\mathbf{\square})$ and $G^{\prime \prime}(\triangle)$.

At the beginning of the kinetic led at $100{ }^{\circ} \mathrm{C}$, the AGSO-ELO preparation could be compared to a liquid of low viscosity. Indeed, the loss modulus $G^{\prime \prime}$ presented a reduced value $\left(G^{\prime \prime} \sim 0.5 \mathrm{~Pa}\right)$ and was even the only characteristic to be measured. The slight increase of $G^{\prime \prime}$ with time was interpreted as being a consequence of the crosslinking reaction between AGSO and ELO. Above a critical time close to $5.5 \mathrm{hr}$, the storage modulus $G^{\prime}$ began to be registered. Its value increased in a faster way than that of $G^{\prime \prime}$ and the elastic contribution became even predominant for $t>6 \mathrm{hr}$. This evolution was identified as representative of the gelation of the system. For higher curing time, the densification of the polymeric network pursued itself but none vitrification was observed even for very long periods. In other words, both viscoelastic moduli tended to asymptotic values due to the progressive consumption of the reactive units but the final mechanical rigidity registered at this study temperature was similar to that of an elastomer. The rheological kinetic performed at the curing temperature of $120{ }^{\circ} \mathrm{C}$ showed a similar evolution as that previously described at $T=100{ }^{\circ} \mathrm{C}$. Due to the temperature activation of the crosslinking process, the liquid-solid transition appeared sooner $(t \sim 2 \mathrm{hr})$. From a practical point of view, these experiments were useful to evaluate the minimum time necessary for the reaction between AGSO and ELO to be achieved at a precise temperature. For instance, at $T=100{ }^{\circ} \mathrm{C}$, the stabilization of the complex shear modulus was observed for $t>14 \mathrm{hr}$.

\section{Thermomechanical Characterization of the Cured Polymer}

A new batch was prepared by mixing AGSO $\left(87 \% \mathrm{NH}_{2}\right)$ and ELO in stoichiometric conditions. The mixture was consecutively poured at room temperature in an aluminum cup and cured at $T=100{ }^{\circ} \mathrm{C}$ during $24 \mathrm{hr}$. These mild conditions made it possible the manufacture of a crosslinked sample without any competing degradation. Finally, its thermomechanical analysis was operated from $-150{ }^{\circ} \mathrm{C}$ to $150{ }^{\circ} \mathrm{C}$ to investigate in particular the glass transition temperature of the cured AGSO-ELO material. The results of the corresponding analysis are plotted in Figure 7.
The overall thermomechanical profile resembled that classically observed with thermoset amorphous polymers. The glassy state of the material, characterized by a high mechanical rigidity $\left(G^{\prime} \sim 10^{9} \mathrm{~Pa}\right)$ was observed for temperature up to $-45{ }^{\circ} \mathrm{C}$. Then, for a temperature comprised between $-45{ }^{\circ} \mathrm{C}$ and $-10{ }^{\circ} \mathrm{C}$, the storage modulus $G^{\prime}$ strongly decreased and at the same time, the $G^{\prime \prime}$ curve presented a relaxation peak. Both phenomena are well-known in rheometry to be associated to the polymer glass transition. Finally, the rubbery state of the material was observed for $T>0{ }^{\circ} \mathrm{C}$.

As the rheological test was performed with a low value of the angular frequency, the temperature taken at the maximum of the $G^{\prime \prime}$ peak could be taken as a reliable evaluation of the glass transition temperature $\left(T_{\mathrm{g}}\right)$ of the cured AGSOELO material. The value get by this way $\left(T_{\mathrm{g}}=-38{ }^{\circ} \mathrm{C}\right)$ agreed with that get by DSC technique (see Supporting Information Fig. 2). The calorimetric experiment did not show any trace of residual crosslinking. Then, the viscoelastic behavior described here was considered as representative of a fully cured AGSO-ELO mixture. Anyway, the $T_{\mathrm{g}}$ of this material was found to be much smaller than that reported in the literature for ELO cured with a tetrahydrophthalic anhydride (THPA) hardener. Corrected at the inception of the decrease of the shear modulus, the $T_{\mathrm{g}}$ of the ELO-THPA was about $80{ }^{\circ} \mathrm{C}^{56}$ This discrepancy was interpreted as a direct consequence of the much higher molecular flexibility of the AGSO hardener compared to THPA. This assessment was also supported by already published data about the influence of the hardener nature on the physicochemical properties of an ELO-based material. ${ }^{57,58}$ The use of a poly(oxypropylene triamine) in place of methyltetrahydrophthalic anhydride produced an important decrease of the $T_{\mathrm{g}}$ of the cured material of more than $100{ }^{\circ} \mathrm{C}$.

\section{CONCLUSIONS}

This article developed the scientific methodology used to produce a polyamine from an unsaturated vegetable oil using the reaction of cysteamine chloride and UV-initiated thiolene chemistry. The influence of different parameters such as the nature and quantity of photoinitiator but also the reaction time was gradually examined using different analytical

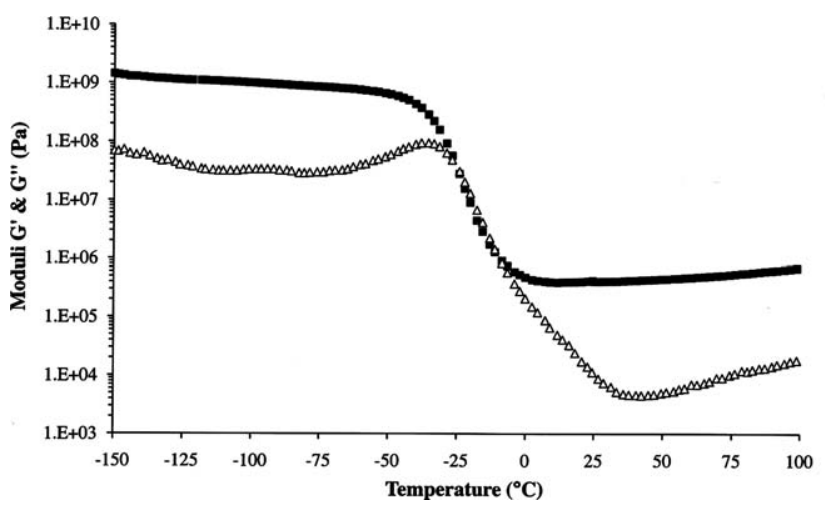

FIGURE 7 Thermomechanical analysis of the cured AGSO-ELO mixture with $G^{\prime}(\square)$ and $G^{\prime \prime}(\triangle)$. 
techniques (FTIR, ${ }^{13} \mathrm{C}$ NMR, and ${ }^{1} \mathrm{H}$ NMR...). The higher conversion rate was evaluated to be about $87 \%$ and the average number of amine units per triglyceride molecule was close to 4.13. The consecutive definition of the epoxidation rate of a chemically modified linseed oil (ELO) allowed the preparation of a reactive mixture in stoichiometric conditions. The temperature domain and the kinetic parameters of the crosslinking reaction were respectively measured by DSC and dynamic rheometry. The latter technique was equally employed to investigate the thermomechanical behavior of the cured polymer. In particular, the glass transition temperature of this fully oil-based material was measured to be of $-38{ }^{\circ} \mathrm{C}$. Finally, it is important to keep in mind that GSO was used as a model compound to demonstrate the feasibility of the amination process. In the same framework, ELO was also chosen as an example of epoxidized oil. In other words, it is reasonable to think that this general approach is likely applicable to other kinds of vegetable oils initially comprised of a significant proportion of unsaturated fatty acids (soybean oil ...).

The authors thank the Region Languedoc-Roussillon and CNRS for their financial support (B.G.). They are also grateful to ARD for a generous gift of ELO. B. Baréa, P. Villeneuve from CIRAD (IATE), and G. Cazals are acknowledged for their technical assistance.

\section{REFERENCES AND NOTES}

1 Raquez, J. M.; Deleglise, M.; Lacrampe, M. F.; Krawczak, P. Prog Polym Sci 2010, 35, 487-509.

2 Guner, F. S.; Yagci, Y.; Erciyes, A. T. Prog Polym Sci 2006, 31, 633-670.

3 Gandini, A. Epoxy Polymers Based on Renewable Resources in Epoxy Polymers: New Materials and Innovations, Pascault, J. P.; Williams, R. J. J., Eds.; Wiley-VCH, 2010, pp 55-78.

4 Boutevin, B.; Chaib, M.; Robin, J. J. Macromol Chem Phys 1990, 191, 737-747.

5 Boutevin, B.; Chaib, M.; Robin, J. J Polym Bull 1991, 26, 177-179.

6 Meier, M. Green Chem 2007, 9, 1356-1361.

7 Giardi, C.; Lapinte, V.; Charnay, C.; Robin, J. J React Funct Polym 2009, 69, 643-649.

8 Piazza, G. J.; Foglia, T. A. J Am Oil Chem Soc 2005, 82, 481-485.

9 Biermann, U.; Friedt, W.; Lang, S.; Luhs, W.; Machmuller, G.; Metzger, J. O.; Klaas, M. R.; Schafer, H. J.; Schneider, M. P. Angew Chem-Int Ed 2000, 39, 2206-2224.

10 Meier, M. A. R.; Metzger, J. O.; Schubert, U. S. Chem Soc Rev 2007, 36, 1788-1802.

11 Tamami, B.; Sohn, S.; Wilkes, G. L. J Appl Polym Sci 2004, 92, 883-891.

12 Man, N.; Mendon, S. K.; Rawlins, J. W.; Thames, S. F. J Am Oil Chem Soc 2008, 85, 791-796.
13 Petrovic, Z. S.; Guo, A.; Zhang, W. J Polym Sci Part A: Polym Chem 2000, 38, 4062-4069.

14 Kozlowski, R.; Pielichowski, J.; Prociak, A.; Marek, M.; Bujnowicz, K. Raw Materials Based on Linseed Oils for Polyurethane Synthesis; Anandjiwala, R.; Hunter, L.; Kozlowski, R.; Zaikov, G., Eds.; Nova Science Publishers: Hauppauge, 2007; pp 397-403.

15 Chakrapani, S.; Crivello, J. V. J Macromol Sci-Pure Appl Chem 1998, A35, 691-710.

16 Tellez, G. L.; Vigueras-Santiago, E.; Hernandez-Lopez, S.; Bilyeu, B. Des Monomers Polym 2008, 11, 435-445.

17 Czub, P. Polym Adv Technol 2009, 20, 194-208.

18 Biermann, U.; Furmeier, S.; Metzger, J. O. Fett-Lipid 1998, 100, 236-246.

19 Baumann, H.; Buhler, M.; Fochem, H.; Hirsinger, F.; Zoebelein, H.; Falbe, J. Angew Chem Int Ed 1988, 27, 41-62.

20 Zhao, H. P.; Zhang, J. F.; Sun, X. S.; Hua, D. H. J Appl Polym Sci 2008, 110, 647-656.

21 Biswas, A.; Sharma, B. K.; Willet, J. L.; Vermillion, K.; Erhan, S. Z.; Cheng, H. N. Green Chem 2007, 9, 85-89.

22 Biswas, A.; Sharma, B. K.; Willett, J. L.; Erhan, S. Z.; Cheng, H. N. Energy Environ Sci 2008, 1, 639-644.

23 Biswas, A.; Sharma, B. K.; Doll, K. M.; Erhan, S. Z.; Willett, J. L.; Cheng, H. N. J Agric Food Chem 2009, 57, 8136-8141.

24 Dubois, J. L.; Gillet, J. P. Coproduction of Cyclic Carbonates and of Nitriles and/or Fatty Amines. WO Patent 145941, 2008.

25 Earls, J. D.; White, J. E.; Lopez, L. C.; Lysenko, Z.; Dettloff, M. L.; Null, M. J. Polymer 2007, 48, 712-719.

26 Hoyle, C. E.; Lee, T. Y.; Roper, T. J Polym Sci Part A: Polym Chem 2004, 42, 5301-5338.

27 Cramer, N. B.; Reddy, S. K.; Cole, M.; Hoyle, C.; Bowman, C. N. J Polym Sci Part A: Polym Chem 2004, 42, 5817-5826.

28 Boileau, S.; Mazeaud-Henri, B.; Blackborow, R. Eur Polym J 2003, 39, 1395-1404.

29 Boutevin, B.; Hervaud, Y.; Mouledous, G. Polym Bull 1998, 41, 145-151.

30 Ameduri, B.; Boutevin, B.; Nouiri, M. J Polym Sci Part A: Polym Chem 1993, 31, 2069-2080.

31 Boutevin, B.; Hervaud, Y.; Nouiri, M. Eur Polym J 1990, 26, 877-882.

32 Lucas, P.; Fleury, E.; Estur, J. F.; Lapinte, V.; Robin, J. J Macromol Chem Phys 2009, 210, 1933-1941.

33 Bantchev, G. B.; Kenar, J. A.; Biresaw, G.; Han, M. G. J Agric Food Chem 2009, 57, 1282-1290.

34 Schwab, A. W.; Gast, L. E.; Rohwedder, W. K. J Am Oil Chem Soc 1976, 53, 762-766.

35 Samuelsson, J.; Jonsson, M.; Brinck, T.; Johansson, M. J Polym Sci Part A: Polym Chem 2004, 42, 6346-6352.

36 Lluch, C.; Ronda, J. C.; Galia, M.; Lligadas, G.; Cadiz, V. Biomacromolecules 2010, 11, 1646-1653. 
37 Lligadas, G.; Ronda, J. C.; Galia, M.; Cadiz, V. Biomacromolecules 2010, 11, 2825-2835.

38 Black, M.; Rawlins, J. W. Eur Polym J 2009, 45, 5, 14331441.

39 Türünc, O.; Meier, M. A. R. Macromol Rapid Commun 2010, 31, 1822-1826.

40 Sharma, B. K.; Adhvaryu, A.; Erhan, S. Z. J Agric Food Chem 2006, 54, 9866-9872.

41 Bexell, U.; Olsson, M.; Johansson, M.; Samuelsson, J.; Sundell, P. E. Surf Coatings Technol 2003, 166, 141-152.

42 Boquillon, N. J Appl Polym Sci 2006, 101, 4037-4043.

43 Shabeer, A; Garg, A; Sundararaman, S; Chandrashekhara, K.; Flanigan, V.; Kapila, S. J Appl Polym Sci 2005, 98, 17721780.

44 Gunstone, F. D.; Harwood, J. L.; Dijkstra, A. J. The Lipid Handbook, 3rd ed.; CRC Press, 2007, p 47.

45 Boyer, C.; Loubat, C.; Robin, J. J.; Boutevin, B. J Polym Sci Part A: Polym Chem 2004, 42, 5146-5160.

46 Campos, L. M.; Killops, K. L.; Sakai, R.; Paulusse, J. M. J.; Damiron, D.; Drockenmuller, E.; Messmore, B. W.; Hawker, C. J. Macromolecules 2008, 41, 7063-7070.

47 Brummelhuis, N.; Diehl, C.; Schlaad, H. Macromolecules 2008, 41, 9946-9947.
48 Justynska, J.; Hordyjewicz, Z.; Schlaad, H. Polymer 2005, 46 , 12057-12064.

49 Fouassier, J. P.; Rabek, J. F. Radiation Curing in Polymer Science and Technology, Vol. 3: Polymerization Mechanisms; Elsevier: England, 1993.

50 Chatgilialoglu, C.; Samadi, A.; Guerra, M.; Fischer, H. ChemPhysChem 2005, 6, 286-291.

51 Desroches, M.; Caillol, S.; Lapinte, V.; Auvergne, R.; Boutevin, B. Macromolecules, in press.

52 Cramer, N. B.; Bowman, C. N. J Polym Sci Part A: Polym Chem 2001, 39, 3311-3319.

53 Fouassier, J. P.; Allonas, X.; Lalevée, J.; Dietlin, C. Photochemistry and Photophysics of Polymer Materials, Allen N. S., Ed.; Wiley, 2010; pp 351-419.

54 Nassiet, V.; Habas, J. P.; Hassoune-Rhabbour, B.; Baziard, Y; Petit, J. A. J Appl Polym Sci 2006, 5, 679-690.

55 Shabeer, A.; Sundararaman, S.; Chandrashekhara, K.; Dharani, L. R. J Appl Polym Sci 2007, 105, 656-663.

56 Boquillon, N.; Fringant, C. Polymer 2000, 41, 8603-8613.

57 Miyagawa, H.; Mohanty, A. K.; Misra, M. Macromol Mater Eng 2004, 289, 629-635.

58 Miyagawa, H.; Mohanty, A. K.; Misra, M; Macromol Mater Eng 2004, 289, 636-641. 